stimulated than on the particular receptor cells. But it is becoming more and more certain that there are marked differences in the specific sensitivity of the receptors. One group will react most readily to aromatic molecules, another to particular terpenes and so on. These differences are no doubt permanent, but they show that cells which look alike may have some physico-chemical organization which makes them react quite differently to a particular stimulus. It is perhaps to be hoped that the cells of our brain have a more uniform constitution, and that memory traces depend on biophysical rather than biochemical alterations. It will certainly be easier to detect the former; yet until we know more about the nature of these traces, we cannot begin to understand what is by far the most important property of the brain.

\section{OIL POLLUTION OF THE SEA}

A

$\mathrm{T}$ the International Conference on Oil Pollution of the Sea, which was held in the Lecture Hall of the Institution of Electrical Engineers, Savoy Place, London, on October 27, representative private citizens of many nations met together for the first time in a concerted effort to press for action on the evils caused by oil pollution of the sea. The Conference was organized by the Co-ordinating Advisory Committee on Oil Pollution of the Sea, of which Mr. James Callaghan is chairman. This is an independent Committee composed of representatives of the interests in Great Britain which are most affected by oil pollution, namely : Association of Municipal Corporations, Association of Sea Fisheries Committees of England and Wales, Council for the Preservation of Rural England, Council for the Preservation of Rural Wales, County Councils Association, General Council of British Shipping, International Committee for Bird Preservation (British Section), River Boards Association, Royal Society for the Prevention of Cruelty to Animals, Royal Society for the Protection of Birds, Rural District Councils Association, Universities Federation for Animal Welfare and the Urban District Councils Association, with individual members who are experts on different aspects of the question.

In the formation of the Committee in March 1952, the efforts of many organizations which had for years been working individually to secure a solution of the problem of oil pollution were coordinated and canalized. On July 21, 1952, the Minister of Transport announced in the House of Commons that he had decided to appoint a committee to consider what measures could be taken to prevent oil pollution of the sea, and on October 2 the constitution of this committee, which was entitled the Committee on the Prevention of Pollution of the Sea by Oil, under the chairmanship of Mr. P. Faulkner, was announced. The report of this Committee was published in July this year, and the purpose of the Conference just organized by the independent Co-ordinating Advisory Committee on Oil Pollution of the Sea, and presided over by Mr. J. Callaghan, was to bring the findings of this report before public opinion in all countries.

In opening the Conference, the Minister of Transport, Mr. Alan Lennox-Boyd, stated that it is realized in the United Kingdom that legislation is required to implement the recommendations of the Faulkner Report; but it is also recognized that action by one country alone, though important, is not enough. He then announced that the Government is taking steps to call a conference of maritime governments to consider how the trouble could be ended. $\mathrm{He}$ had in mind that it might be similarly organized to the Conference on Safety at Sea, held in 1948, which was followed by swift action, and concluded by stating that he hoped its recommendations would be as speedily adopted.

Lord Hurcomb, president of the Society for the Promotion of Nature Reserves and, until recently, chairman of the British Transport Commission, in introducing the report of the Minister of Transport's committee on oil pollution, stated that there is no dispute as to the gravity and extent of the mischief, nor is there any room for dispute as to the cause of the trouble or the remedies for it. The remedies are clear, and all that is needed is the will to apply them. $\mathrm{He}$ pointed out that the Minister's committee, which included two shipowners and two representa. tives of the oil companies, has stated in its report that "in recent years the nuisance has become intolerable". $\mathrm{He}$ expressed appreciation for the speed and admirable precision with which the committee has reported, and said that its inquiries have been thorough and it has pointed firmly and fearlessly to the remedies, after satisfying itself that those remedies are entirely practicable. Lord Hurcomb continued that the problem reduces to the fact that the only way to avoid polluting the sea, fouling the beaches and destroying birds, is not to put persistent oil sludges and waste into the ocean, but to separate them and to discharge them ashore. To prohibit discharge within a prescribed distance of particular coasts is a mere palliative, though necessary as an interim measure. It has been shown that even a limit of 150 miles would not give the United Kingdom a remedy, and the only long-term policy is to prevent the discharge of persistent oils into the sea altogether. For this to be practicable, suitable and adequate facilities for the reception of oily waste should be provided at all loading terminals and repair ports throughout the world. Lord Hurcomb concluded by stating that weary years of international argument in the hope of securing complete agreement should not be contemplated, and asked that a date for achieving the ultimate policy should not be timidly fixed too far ahead.

Mr. Donald F. Anderson, chairman of the General Council of British Shipping, spoke on the problem as the British shipowner sees it and stated that their general attitude is already known by the solid fact that British shipowners have accepted the report and recommendations of the Faulkner Committee, and that they decided as soon as it came out to put into practice some of the measures. He stressed that, though they are doing all they can to help in solving the problem, it would take more than action by British shipowners before there could be any material improvement, and he alluded to the vast amount of shipping under other flags which goes up and down the English Channel without touching the United Kingdom. He concluded by saying that goodwill among shipowners of the leading maritime countries is not enough. If the aim of preventing oil getting into the sea anywhere is to be reached, this can only be achieved if vessels of all flags are bound by a convention among all the nations with ships that sail the seas. 
Sir Douglas Ritchie, chairman of the Executive Committee of the Dock and Harbour Authorities Association, pointed out how difficult it has proved to detect offenders under the Oil in Navigable Waters Act, particularly as some part of the pollution of inland tidal waters is caused by oil discharged, or escaping, many miles away at sea and being carried to the coasts. He described the facilities which have been provided for the collection of oily water in ports and stated that these have, unfortunately, not been used to any real extent. His Association welcomes the recommendations of the Faulkner Committee and has made it clear that it would be prepared to co-operate in providing, or securing the provision of, adequate reception facilities at the ports.

In May 1952 an independent Scandinavian Committee on Oil Pollution of the Sea, consisting of representatives from Finland, Sweden, Norway and Donmark, was set up at an international meeting of sportsmen in Finland. This committee was represented at the London Conference by its chairman, Captain Berno von Bornstedt, and Major Bertil Funck (Sweden), with Mr. Mogens Blach, director of the Port of Copenhagen, and Mr. MoltkeLeth, of the Danish Hunting Society. Mr. Blach described the havoc caused by oil pollution on Danish shores and mentioned the voluntary efforts in abstaining from the discharge of waste oil made by Danish shipowners. He said that it is understood in Denmark that the evil cannot be eliminated until international agreement is reached, and it is felt that it is the duty of any interested country to do everything possible to have the question dealt with on an international basis. Major Bertil Funck outlined the measures regarding oil pollution which have been taken in Sweden and referred to the recommendations which were made at the Baltic and International Maritime Conference in Stockholm in 1951. He stated that the Scandinavian Committee supports the recommendations of the British report and proposes that the Scandinavian Governments should. as soon as possible, seek the agreement of the Baitic and North Sea countries for fixing a date after which discharge of persistent oils into the sea should be prohibited.

A report from Mr. Banks Belt, chairman of the Atlantic Waterfowl Council, New York, directed special attention to the need for educating crews in care in preventing oil pollution.

Dr. H. Lillie, formerly a surgeon with an antarctic whaling fleet, urged that whatever legislation is introduced internationally should cover operations of the whaling industry in the Antarctic and other seas. He described half-grown seals covered in a thick tarry mess, their eyes bloodshot with irritation, and penguins hopelessly clogged waiting a slow death.

Sir John Simonsen, speaking on the need for further research, stated that the separation of oil-water emulsions is not a problem easy of solution. What is required is a plant cheap to buy, occupying little space and requiring for its operation the minimum of technical control. Plants and methods are in use which have proved successful, but further work is necessary. If governments insist, and it is hoped they will, that oil pollution must cease, research on this problem might well be undertaken in a govern ment research institute. It would require the joint work of a physical chemist and chemical engineer. Two speakers described plants for dealing with waste oil, and Mr. W. Killner stated that the process he has developed while in Admiralty service does not require specialized technique or elaborate equipment and is suitable for use in merchant ships. Full information is in the hands of the National Research Development Corporation.

At the close of the Conference a declaration of aims was unanimously adopted, supporting the view that ships of all nations should be required to refrain from discharging persistent oils into the sea, noting with satisfaction the co-operation of the shipping industry and oil companies, recognizing the need for international agreement and undertaking to stimulate public opinion regarding this, welcoming the announcement of the Minister of Transport regarding the calling of an international conference and urging that statutory provision be made to ensure adequate facilities for the reception of oily residues at ports, oil-loading terminals and repair yards.

In addition to the representatives of Belgium, Denmark, Finland, Sweden, Norway, the Netherlands and South Africa who attended the Conference, twenty-six nations were represented by observers from their embassies, legations, diplomatic missions and high commissioners in London.

\section{STANDARDIZATION OF RADIOACTIVE ISOTOPES IN GREAT BRITAIN}

\author{
BY W. E. PERRY \\ National Physical Laboratory, Teddington
}

CINCE the end of 1950 , four organizations in $\$$ Great Britain-Atomic Energy Research Establishment, National Physical Laboratory, Radiotherapeutic Research Unit of the Medical Research Council and Royal Cancer Hospital-have been collaborating in the measurement of radioactive isotopes on an absolute basis, that is, in determining the number of disintegrations per second in a given sample. It seems an appropriate moment to review very briefly the work which has been done so far; a fuller report on the measurements (up to the spring of 1953) is obtainable on application to the Director, National Physical Laboratory, Teddington.

The impetus for undertaking this work came partly from the recommendations of the Joint Commission on Radioactivity and of the International Commission on Radiological Units. The aim has been to assess the reliability of different methods, to improve and develop them, and to introduce ultimately a system of standardization appropriate to the more important isotopes, particularly those of relatively short half-life. Some users of radioactive isotopes are, of course, not much concerned with absolute values; but others, for example, clinical users, must have an absolute basis for their work with these substances.

At the outset a short list of the more important isotopes was drawn up, and it was hoped that an accuracy of the order of 2 per cent would be both adequate and attainable in their standardization. By the end of 1952 , samples of ten isotopes had been measured by counting and by ionization-chamber methods. The former included defined solid-angle $\beta$-particle counting with end-window Geiger-Müller 